\title{
Mesh Surgery for Anterior Vaginal Wall Prolapse: A Meta-analysis
}

\section{Cirurgia com tela para correção de prolapso de parede anterior: metanálise}

\author{
Cássia Raquel Teatin Juliato ${ }^{1}$ Luiz Carlos do Santos Júnior ${ }^{1}$ Jorge Milhem Haddad ${ }^{2}$ \\ Rodrigo Aquino Castro ${ }^{3}$ Marcelo Lima ${ }^{1}$ Edilson Benedito de Castro ${ }^{1}$ \\ ${ }^{1}$ Department of Obstetrics and Gynecology, Universidade Estadual de \\ Campinas, Campinas, SP, Brazil \\ 2 Department of Urogynecology, Universidade de São Paulo, São \\ Paulo, Brazil \\ ${ }^{3}$ Department of Obstetrics and Gynecology, Universidade Federal de \\ Address for correspondence Cássia Raquel Teatin Juliato, MD, PhD, \\ Department of Obstetrics and Gynecology, Universidade Estadual de \\ Campinas, Rua Alexander Fleming, 101, Cidade Universitária Zeferino \\ Vaz, 13083-881, Campinas, São Paulo, Brazil \\ (e-mail: cassia.raquel@gmail.com).
} São Paulo, São Paulo, SP, Brazil

Rev Bras Ginecol Obstet 2016;38:356-364.

\author{
Abstract \\ Keywords \\ - anterior pelvic organ \\ prolapse \\ - cystocele \\ - surgery \\ - mesh \\ - colporrhaphy \\ - meta-analysis
}

Purpose Pelvic organ prolapse (POP) is a major health issue worldwide, affecting 6$8 \%$ of women. The most affected site is the anterior vaginal wall. Multiple procedures and surgical techniques have been used, with or without the use of vaginal meshes, due to common treatment failure, reoperations, and complication rates in some studies. Methods Systematic review of the literature and meta-analysis regarding the use of vaginal mesh in anterior vaginal wall prolapse was performed. A total of 115 papers were retrieved after using the medical subject headings (MESH) terms: 'anterior pelvic organ prolapse OR cystocele AND surgery AND (mesh or colporrhaphy)' in the PubMed database. Exclusion criteria were: follow-up shorter than 1 year, use of biological or absorbable meshes, and inclusion of other vaginal wall prolapses. Studies were put in a data chart by two independent editors; results found in at least two studies were grouped for analysis.

Results After the review of the titles by two independent editors, 70 studies were discarded, and after abstract assessment, 18 trials were eligible for full text screening. For final screening and meta-analysis, after applying the Jadad score $(>2), 12$ studies were included. Objective cure was greater in the mesh surgery group (odds ratio $[\mathrm{OR}]=1,28[1,07-1,53])$, which also had greater blood loss (mean deviation [MD] $=45,98[9,72-82,25])$, longer surgery time $(M D=15,08[0,48-29,67])$, but less prolapse recurrence $(\mathrm{OR}=0,22[01,3-0,38])$. Dyspareunia, symptom resolution and reoperation rates were not statistically different between groups. Quality of life (QOL) assessment through the pelvic organ prolapse/urinary incontinence sexual questionnaire (PISQ-12), the pelvic floor distress inventory (PFDI-20), the pelvic floor impact questionnaire (PFIQ-7), and the perceived quality of life scale (PQOL) was not significantly different. received

February 1, 2016

accepted

May 18, 2016

published online

July 23, 2016
DOI http://dx.doi.org/

10.1055/s-0036-1585074. ISSN 0100-7203.
Copyright $\odot 2016$ by Thieme Publicações License terms Ltda, Rio de Janeiro, Brazil
(®) $\Theta \circledast$ 


\section{Resumo \\ Palavras-chave \\ - prolapso pélvico de parede anterior \\ - cistocele \\ - cirurgia \\ - tela \\ - colporrafia \\ - metanálise}

Conclusions Anterior vaginal prolapse mesh surgery has greater anatomic cure rates and less recurrence, although there were no differences regarding subjective cure, reoperation rates and quality of life. Furthermore, mesh surgery was associated with longer surgical time and greater blood loss. Mesh use should be individualized, considering prior history and risk factors for recurrence.

Introdução Prolapso de órgãos pélvicos é problema de saúde públicas, sendo o mais comum o anterior. Para tratamento são utilizadas cirurgias, com ou sem telas. O uso de telas é para diminuir recidivas, mas não $\mathrm{h}$

á consenso.

Métodos Foi realizada revisão da literatura e metanálise, sobre uso de telas na correção do prolapso anterior. Base de dados foi PUBMED , com termos (MESH): "Anterior Pelvic Organ OR Cystocele AND Surgery AND (Mesh or Colporrhaphy)". Critérios de exclusão foram: seguimento menor que 1 ano, telas biológicas ou absorvíveis. Resultados: foram avaliados 115 artigos. Após revisão dos títulos, 70 estudos foram descartados e 18 após leitura de resumos. Após critérios de Jadad (>2), 12 estudos foram incluídos. Análise estatística foi razão de risco ou diferença entre médias dos grupos, e as análises com grande heterogeneidade foram avaliadas através de análise de efeito aleatório.

Resultados Cura objetiva foi superior no grupo com tela - OR 1,28 (1,07-1,53, p $\leq$ 0,00001), maior perda sanguínea - diferença média (MD) 45,98 (9,72-82,25, $p=0,01)$, tempo cirúrgico mais longo - MD 15,08 $(0,48-29,67, \mathrm{p}=0,04)$, porém menor recorrência - OR 0,22 $(0,13-0,38, p=0,00001)$, não apresentando maior resolução dos sintomas - OR 1,93 $(0,83-4,51, p=0,15)$. Dispareunia e taxa de reoperação também não foram diferentes entre grupos. Qualidade de vida não apresentou diferença.

Conclusões Cirurgia com tela para prolapso vaginal anterior apresenta melhor taxa de cura anatômica e menor recorrência, sem diferenças cura subjetiva, reoperação e qualidade de vida. Há maior tempo cirúrgico e perda sanguínea. Uso de telas deve ser individualizado.

\section{Introduction}

Pelvic organ prolapse (POP) is a major health issue worldwide, and even nowadays it represents a great challenge to modern gynecology. ${ }^{1-3}$ In epidemiologic surveys, "vaginal bulge" sensation reaches up to $6-8 \%$ of all female interviewees; and if pelvic examination alone is considered, the numbers rise to $30-60 \%$ of all women. ${ }^{4,5}$ POP diagnosis goes back to Antiquity, and multiple treatments and theories have been tried and abandoned over the years, with frequent recurrence and uncertain success rates. ${ }^{3}$

The anterior vaginal wall is the most commonly affected, being responsible for up to $80 \%$ of all POP surgical procedures. $^{2}$ The possible reasons for this dominance lie on its anatomical characteristics, in that the anterior vaginal wall lies on a more horizontal position in the female pelvis, suffering further gravitational pressure, without having any muscle support; moreover, the tissue separating the anterior vaginal wall from the bladder is comparatively thinner and more distensible than that enfolding the other vaginal walls. ${ }^{2,4}$
Several surgical techniques have arisen and been discharged over the years. ${ }^{3}$ High recurrence rates and complications in POP surgery led to the development of meshes for the anterior vaginal wall since the 1950's - from biological meshes, autologous (fascia) and heterologous (porcine), to synthetic ones, both absorbable and non-absorbable, with conflicting results and alarming complication rates in some series. ${ }^{1,3,5}$

Recent studies revealed that synthetic meshes seem superior to biological ones, and both produce better anatomical outcomes when compared with simple colphorraphy - however, with higher complication rates, such as larger intraoperative bleeding, slower surgical time and greater extrusion rates, and apparently without significant differences in the quality of life questionnaire assessment, although long follow-up studies on this issue are rare.

The main goal of this meta-analysis is to evaluate the effectiveness of POP surgery and its complications, emphasizing the anterior vaginal wall, with and without mesh use. 


\section{Methods}

A systematic review and meta-analysis was conducted on the effectiveness and complications regarding women treated for anterior vaginal wall prolapse surgically, comparing mesh treatment with traditional surgery.

For a complete original article search, the following steps were covered, according to the preferred reporting items for systematic reviews and meta-analyses (PRISMA) ${ }^{6}$ statement - search in the PubMed database with the medical subject headings (MESH) terms: 'anterior pelvic organ prolapse OR cystocele AND surgery AND (mesh or colporrhaphy)'.

Inclusion criteria: Randomized controlled trials, in English, published in the past 15 years, including only women with anterior vaginal wall prolapse, comparing surgical treatment without mesh versus using synthetic absorbable meshes.

A total of 115 articles, after filtering results by species (human), gender (female) and language (English), were recovered. The last online search was performed on June 20th, 2015. After excluding duplicate series, identified by abstract reading, a total of 109 articles were included for final screening. The inclusion process was performed by two independent reviewers (EBC, and LCS).

Exclusion criteria were the following: articles regarding other vaginal walls or incontinence as a main result; followup shorter than one year; anatomic evaluation made without the use of the pelvic organ prolapse quantification (POP-Q) ${ }^{7}$ rating; literature or systematic reviews; studies using biological or absorbable meshes; and uncontrolled/non randomized trials.

Initially, the articles were selected by their titles/abstracts; afterwards, full text articles that potentially met all the inclusion criteria were assessed. Whenever there was lack of accordance between the two reviewers, a third researcher was consulted (CRTJ). After this initial screening, included articles were submitted to $\operatorname{Jadad}^{8}$ criteria, and only papers for which the Jadad score was greater than 2 were finally included.

In the papers where the inclusion criteria were met, assessed data were: objective cure; surgery time; intraoperative blood loss; recurrence rate; reoperation rate (for surgical failure); "vaginal bulge" complaint resolution rate; dyspareunia; and subjective cure through quality of life questionnaires -pelvic organ prolapse/urinary incontinence sexual questionnaire (PISQ-12); ${ }^{9}$ pelvic floor distress inventory (PFDI-20); ${ }^{10}$ pelvic floor impact questionnaire (PFIQ7); ${ }^{10}$ and perceived quality of life scale (P-QOL ). ${ }^{11}$

Outcomes verified in more than two articles were grouped for meta-analysis. A chart for data collection was created to extract the data of interest in each article, which were then retyped to a single database by two independent researchers, to avoid loss of data or mistyping of any kind. The bias risk was assessed by the use of a Cochrane Collaboration tool. ${ }^{12}$

The statistical analysis for outcomes measured in proportion (dichotomous) used the Mantel-Haenszel test, assessing the risk ratio between the groups. The statistical analysis for quantitative outcomes (with averages and standard deviations) assessed the mean difference between the groups.

The heterogeneity between studies was assessed through Chi-square test of study homogeneity and through the $\mathrm{I}^{2}$ index, which varies from $0-100 \%$, where: $0-40 \%$ : there is no significant heterogeneity; 30-60\%: there may be moderate heterogeneity; 50-90\%: there may be substantial heterogeneity; $75-100 \%$ : there is plenty of heterogeneity between studies.

For studies with heterogeneity superior to $50 \%$ and $p<0.05$, a random effect meta-analysis was performed. ${ }^{13}$ The computer system utilized was the Review Manager 5.3 (IKMD, Copenhagen, Denmark). ${ }^{12}$

\section{Results}

Search strategy crossing the terms "Anterior pelvic organ prolapse OR cystocele AND surgery AND (mesh or colporrhaphy)" was conducted in the PubMed online database. A total of 115 articles were retrieved, which came down to 109 after the exclusion of repeated series through title/abstract analysis. Afterwards, 70 articles were discarded by the title due to failure to meet the inclusion criteria.

Two independent reviewers assessed the 39 remaining abstracts, and finally 18 papers were included for eligibility analysis. After full article evaluation, another 4 articles were excluded, with 14 remaining to be submitted to Jadad $^{8}$ score assessment. Two more articles were excluded for Jadad scores under 3, with 12 articles included for final analysis (-Fig. 1 and -Table 1 ).

\section{Objective Cure}

For objective cure analysis, all 12 articles were included ( 1,540 women), with $86 \%$ heterogeneity ( $p<0.00001)$. Patients in the mesh surgery group were considered cured in $551 / 781$ cases, whereas 418/759 women were found cured in the surgery without mesh group, with 1.28 (confidence interval, $\mathrm{CI}=1.07-1.53$ ) greater objective cure risk in the group submitted to mesh surgery, after aleatory effect metaanalysis (-Fig. 2).

\section{Surgery Duration}

For the analysis of surgery duration, 5 articles were included (779 women), with great heterogeneity. After aleatory effect meta-analysis, the group of women submitted to surgery without mesh was found to have less surgical time, with mid difference of 15.08 minutes $(\mathrm{CI}=0.48-29.67)$.

\section{Blood Loss}

For blood loss assessment, 3 articles were included (631 women), with substantial heterogeneity. After aleatory effect analysis, the mesh surgery group was found to have greater blood loss, with a mean difference of $45.98 \mathrm{ml}(\mathrm{Cl}$ $=9.72-82.25$ ).

\section{Prolapse Recurrence}

Five articles were included for recurrence rate analysis (585 women), without significant heterogeneity among them. The 


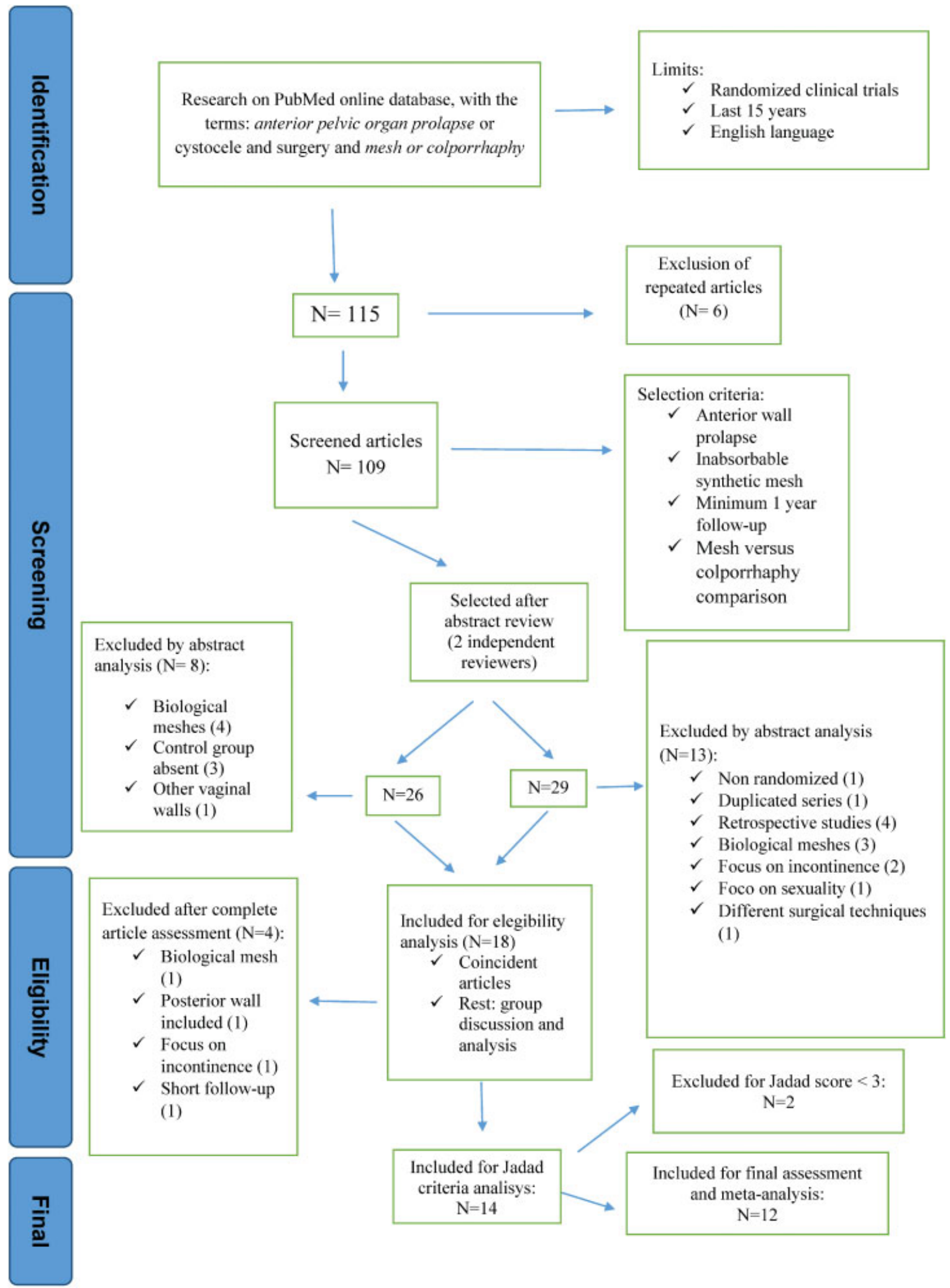

Fig. 1 Articles inclusion criteria or pelvic organ prolapse surgery and its complications. 
Table 1 Articles that evaluated effectiveness of Pelvic Organ Prolapse surgery and its complications

\begin{tabular}{|c|c|c|c|c|c|c|c|c|c|}
\hline Articles & $\mathrm{N}$ & Mesh & Follow-up & $\begin{array}{l}\text { Objective cure } \\
\text { (POP-Q) }\end{array}$ & QOL & Subjective cure & Complications & $\begin{array}{l}\text { Complication } \\
\text { rates }\end{array}$ & Conclusion \\
\hline Altman et al ${ }^{14}$ & 410 & Prolift & 1 year & $\begin{array}{l}S<2+\text { UDI } \\
\text { (question } 16 \text { ) } \\
60.8 \times 34.5 \%\end{array}$ & $\begin{array}{l}\text { UDI } \\
\text { PISQ-12 }\end{array}$ & $\begin{array}{l}\text { "asymptomatic" } \\
75.4 \times 62.1 \% \\
\text { UDI-5 } \\
24.2 \times 17.7 \\
\text { UDI-0 } \\
8.7 \times 12.3 \\
\text { PISQ-12 }\end{array}$ & $\begin{array}{l}\text { Duration } \\
52.6 \times 33.5 \text { minute } \\
\text { Blood loss } \\
84.7 \times 35.4 \mathrm{~mL} \\
\text { Bladder perforation } \\
7 \times 1 \\
\text { Pain } 5 \times 0 \\
\text { Retention } \\
16 \times 6 \\
\text { Cystoscopy } \\
11 \times 1\end{array}$ & $\begin{array}{l}\text { Extrusion } \\
3.2 \%\end{array}$ & $\begin{array}{l}\text { Greater short time } \\
\text { success. with great- } \\
\text { er complications }\end{array}$ \\
\hline de Tayrac et al ${ }^{15}$ & 163 & Ugytex & 1 year & $\begin{array}{l}S<2 \\
89 \times 64 \%\end{array}$ & $\begin{array}{l}\text { PFDI } \\
\text { PFIQ } \\
\text { PISQ-12 } \\
\text { MHU }\end{array}$ & $\begin{array}{l}\text { PFDI (question 5) } \\
31.3 \times 52.2 \\
\text { PISQ-12 } \\
28.5 \times 30.3 \\
\text { "satisfied" } \\
96 \times 92 \%\end{array}$ & $\begin{array}{l}\text { Dyspareunia } \\
20 \times 27.3 \% \\
\text { Hospital stay } \\
4.3 \times 4.7 \text { days } \\
\text { Abnormal bleeding } \\
1 \times 3 \\
\text { Pain } \\
28 \times 15 \%\end{array}$ & $\begin{array}{l}\text { Extrusion } \\
9.5 \%\end{array}$ & $\begin{array}{l}\text { Greater anatomic } \\
\text { success. with slight } \\
\text { increase in compli- } \\
\text { cation rates }\end{array}$ \\
\hline Delroy et al ${ }^{16}$ & 79 & Nazca TC & 1 year & $\begin{array}{l}S<2 \\
82.5 \times 56.4 \%\end{array}$ & $\mathrm{P}-\mathrm{QOL}$ & $\begin{array}{l}\text { General improvement } \\
\text { (not significant) }\end{array}$ & $\begin{array}{l}\text { Duration } \\
99.1 \times 46 \text { minutes } \\
\text { Hospital stay } \\
3.2 \times 3.3 \text { days } \\
\text { Abnormal bleeding } \\
45 \times 30.8 \% \\
\text { Dyspareunia } \\
5 \times 10.2 \%\end{array}$ & $\begin{array}{l}\text { Extrusion } \\
5.0 \%\end{array}$ & $\begin{array}{l}\text { Anatomical im- } \\
\text { provement with } \\
\text { equivalent compli- } \\
\text { cations and QOL }\end{array}$ \\
\hline El-Nazer et al ${ }^{17}$ & 40 & Gynemesh & 2 years & $\begin{array}{l}\mathrm{S}<2 \\
95 \times 70 \% \\
\text { PFMS (perineal strength) }\end{array}$ & $\mathrm{P}-\mathrm{QOL}$ & $\begin{array}{l}\text { "bulge" resolution } \\
94.7 \times 68.4 \% \\
\text { "Voiding dysfunction" } \\
\text { resolution } \\
93.3 \times 66.7 \%\end{array}$ & $\begin{array}{l}\text { Duration } \\
75 \times 76 \text { minutes } \\
\text { Hospital stay } \\
2.6 \times 2.6 \text { days } \\
\text { Blood loss } \\
215.5 \times 219.5 \mathrm{~mL} \\
\text { Bladder perforation: } 0\end{array}$ & $\begin{array}{l}\text { Extrusion } \\
5 \% \\
\text { Recurrence } \\
5 \times 15 \%\end{array}$ & $\begin{array}{l}\text { Anatomical and } \\
\text { functional } \\
\text { improvement }\end{array}$ \\
\hline Gutman et al ${ }^{18}$ & 65 & Prolift & 3 years & $\begin{array}{l}S<2 \\
45 \times 43 \%\end{array}$ & $\begin{array}{l}\text { PFDI } \\
\text { PFIQ } \\
\text { PGI-I } \\
\text { PISQ-12 }\end{array}$ & $\begin{array}{l}\text { "bulge" resolution } \\
92 \times 81 \% \\
\text { "feels better" } \\
88 \times 81 \%\end{array}$ & $\begin{array}{l}\text { Dyspareunia } \\
2 \times 1\end{array}$ & $\begin{array}{l}\text { Extrusion } \\
15 \% \\
\text { Reoperation } \\
13 \times 0 \%\end{array}$ & $\begin{array}{l}\text { Non significant ana- } \\
\text { tomical and subjec- } \\
\text { tive improvement in } \\
\text { both groups }\end{array}$ \\
\hline Hiltunen et al ${ }^{19}$ & 202 & $\begin{array}{l}\text { Parietene } \\
\text { (manufact.) }\end{array}$ & 1 year & $\begin{array}{l}S<2 \\
93.3 \times 61.5 \%\end{array}$ & "symptoms" & $\begin{array}{l}\text { "bulge" resolution } \\
93 \times 94 \% \\
\text { Voiding dysfunction } \\
9 \times 8 \% \\
\text { De novo incontinence } \\
23 \times 10 \%\end{array}$ & $\begin{array}{l}\text { Duration } \\
73 \times 58 \text { minutes } \\
\text { Blood loss } \\
190 \times 114 \mathrm{~mL} \\
\text { Bladder perforation } 1 \times 0 \\
\text { Urinary retention } \\
13 \times 5\end{array}$ & $\begin{array}{l}\text { Extrusion } \\
17.3 \% \\
\text { Recurrence } \\
\text { (symptomatic) } \\
4 \times 15 \%\end{array}$ & $\begin{array}{l}\text { Anatomical im- } \\
\text { provement with re- } \\
\text { currence reduction } \\
\text { and bigger inconti- } \\
\text { nence rates }\end{array}$ \\
\hline Lamblin et $\mathrm{al}^{20}$ & 68 & Perigree & 2 years & $\begin{array}{l}S<2 \\
100 \times 84.4 \%\end{array}$ & $\begin{array}{l}\text { PFDI-20 } \\
\text { PFIQ-7 } \\
\text { POP-QOL } \\
\text { VAS } \\
\text { "sexuality" }\end{array}$ & $\begin{array}{l}\text { PFIQ-7 } \\
28 \times 23 \\
\text { PFID-20 } \\
49 \times 40\end{array}$ & $\begin{array}{l}\text { Duration } \\
69.7 \times 74.6 \text { minute } \\
\text { Hospital stay } \\
4.4 \times 4.6 \text { days } \\
\text { Abnormal bleeding } \\
0 \times 3 \% \\
\text { Retention } \\
0 \times 5.8 \%\end{array}$ & $\begin{array}{l}\text { Extrusion } \\
6 \% \\
\text { Recurrence } \\
0 \times 11.7 \%\end{array}$ & $\begin{array}{l}\text { Greater anatomic } \\
\text { results with equiva- } \\
\text { lent } \mathrm{QOL} \text { and slight- } \\
\text { ly greater morbidity }\end{array}$ \\
\hline Nguyen et a $\left.\right|^{21}$ & 76 & Perigree & 2 years & $\begin{array}{l}S<2 \\
89 \times 55 \%\end{array}$ & $\begin{array}{l}\text { PFDI-20 } \\
\text { PFIQ-7 } \\
\text { PISQ-12 }\end{array}$ & $\begin{array}{l}\text { PFDI-20 } \\
34+-31 \times 45+-32 \\
\text { PFIQ-7 } \\
14+-23 \times 23+-31 \\
\text { PISQ-12 } \\
34 \times 33\end{array}$ & $\begin{array}{l}\text { Hemoglobin drop } \\
2.4 \times 1.8 \\
\text { Dyspareunia } \\
9 \times 16 \%\end{array}$ & $\begin{array}{l}\text { Extrusion } \\
5 \% \\
\text { Recurrence } \\
0 \times 3 \%\end{array}$ & $\begin{array}{l}\text { Better anatomical } \\
\text { results (best for pa- } \\
\text { tients with high risk } \\
\text { for recurrence) }\end{array}$ \\
\hline Nieminen et $\mathrm{al}^{22}$ & 202 & $\begin{array}{l}\text { Parietene } \\
\text { (manufactured) }\end{array}$ & 3 years & $\begin{array}{l}S<2 \\
91 \times 65 \%\end{array}$ & $\begin{array}{l}\text { Non } \\
\text { validated score }\end{array}$ & $\begin{array}{l}\text { Score "bulge" } \\
1.16 \times 1.43\end{array}$ & $\begin{array}{l}\text { De novo incontinence } \\
7 \times 5 \%\end{array}$ & $\begin{array}{l}\text { Extrusion } \\
19 \% \\
\text { Recurrence } \\
13 \times 41 \% \\
\text { Reoperation } \\
11 \times 18 \%\end{array}$ & $\begin{array}{l}\text { Better anatomical } \\
\text { results with equiva- } \\
\text { lent symptom reso- } \\
\text { lution. but high } \\
\text { extrusion }\end{array}$ \\
\hline Sivaslioglu et al ${ }^{23}$ & 90 & Parietene & 1 year & $\begin{array}{l}S<2 \\
91 \times 72 \%\end{array}$ & $\mathrm{P}-\mathrm{QOL}$ & $\begin{array}{l}\mathrm{P}-\mathrm{QOL} \\
6.2+-5.5 \times \\
7.5+-6.2\end{array}$ & $\begin{array}{l}\text { Dyspareunia } \\
4.6 \times 0 \% \\
\text { De novo incontinence } \\
0 \times 7 \%\end{array}$ & $\begin{array}{l}\text { Extrusion } \\
6.9 \% \\
\text { Failure } \\
9.3 \times 28.5 \%\end{array}$ & $\begin{array}{l}\text { Better anatomical } \\
\text { results }\end{array}$ \\
\hline Tamanini et $\mathrm{al}^{24}$ & 100 & Naxca TC & 1 year & $\begin{array}{l}S<2 \\
83.7 \times 55.5 \%\end{array}$ & ICIQ-VS & $\mathrm{QOL}$ and sexuality & $\begin{array}{l}\text { Dyspareunia } \\
2.3 \times 0 \% \\
\text { bleeding }(<500 \mathrm{~mL}) \\
2.3 \times 1.8 \%\end{array}$ & $\begin{array}{l}\text { Extrusion } \\
9.3 \%\end{array}$ & $\begin{array}{l}\text { Better anatomical } \\
\text { results without QOL } \\
\text { difference }\end{array}$ \\
\hline Vollebregt et al ${ }^{25}$ & 125 & Avaulta & 1 year & $\begin{array}{l}S<2 \\
91 \times 41 \%\end{array}$ & $\begin{array}{l}\text { UDI } \\
\text { IIQ }\end{array}$ & $\begin{array}{l}\text { QOL equivalent } \\
\text { (asymptomatic } \\
\text { recurrences) }\end{array}$ & $\begin{array}{l}\text { Dyspareunia } \\
15 \times 9 \% \\
\text { Blood loss } 77 \times 69 \mathrm{~mL} \\
\text { Hospital stay } 3 \times 3 \text { days }\end{array}$ & $\begin{array}{l}\text { Extrusion } 4 \% \\
\text { Reoperation } \\
0 \times 5 \%\end{array}$ & $\begin{array}{l}\text { Better anatomical } \\
\text { results. without sig- } \\
\text { nificant QOL } \\
\text { difference }\end{array}$ \\
\hline
\end{tabular}

Abbreviations: ICIQ-VS, international consultation of incoherence modular questionnaire vaginal symptoms; IIQ, incontinence impact questionnaire; MHU, urinary dysfunction measurement scale PGI-I, patient global impression of improvement; S, stage; UDI, urogenital distress inventory; PFDI, pelvic floor distress inventory, PFDI-20, 20 questions; PFIQ, pelvic floor impact questionnaire; PFIQ-7, seven questions; PFMS, pressure and fluid management symptoms; PISQ-12, pelvic organ prolapse/ urinary incontinence sexual questionnaire; POP-Q, pelvic organ prolapse quantification; QOL, quality of life; UDI, urogenital distress inventory; UDI-0, obstructive discomfort; UDI-5, irritative symptoms; UDI-S, stress symptoms; 


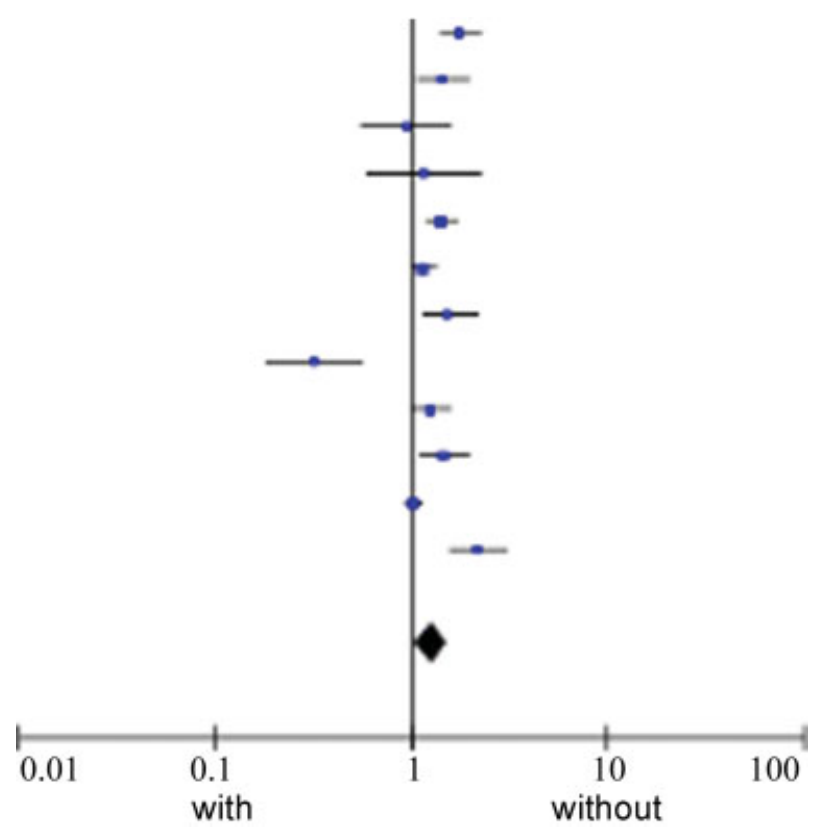

Fig. 2 Objective cure rates after surgery with and without vaginal mesh.

mesh surgery group had 19 recurrences in 300 patients, while the group without mesh had 62 cases in 285 women the mesh group had less recurrence: $\mathrm{OR}=0.22(\mathrm{CI}=0.13-$ 0.38) (-Fig. 3).

\section{Prolapse Related Reoperation}

Three articles were considered for this analysis, totaling 357 women. Mesh surgery patients were reoperated 15/183 cases, whereas in the group without mesh, 21/174 patients had new surgical POP related procedures, with no significant difference between groups: $\mathrm{OR}=0.65(\mathrm{CI}=0.83-4.51)$ (-Fig. 4).

\section{Subjective cure}

For the analysis of subjective cure rates, considering "vaginal bulge" symptom resolution, 3 articles were selected (282 women). The mesh surgery group had vaginal bulge resolution in $135 / 144$ patients, whereas $122 / 138$ women in

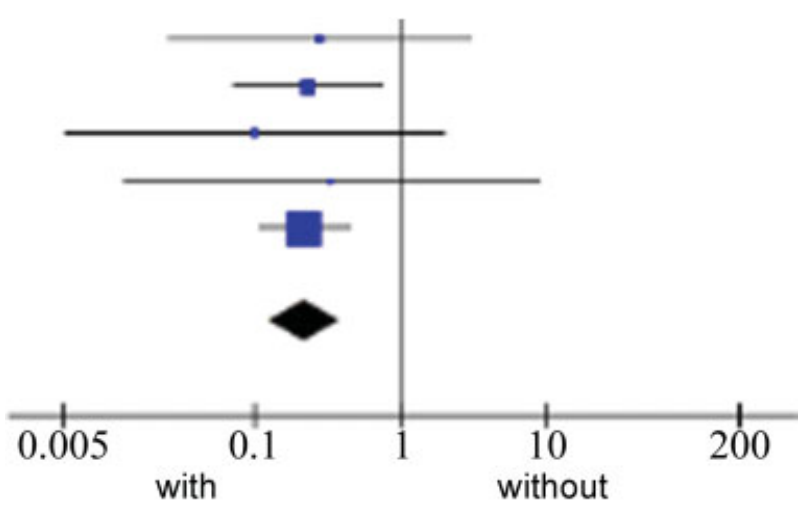

Fig. 3 Recurrence rate in surgery for POP with and without vaginal mesh.

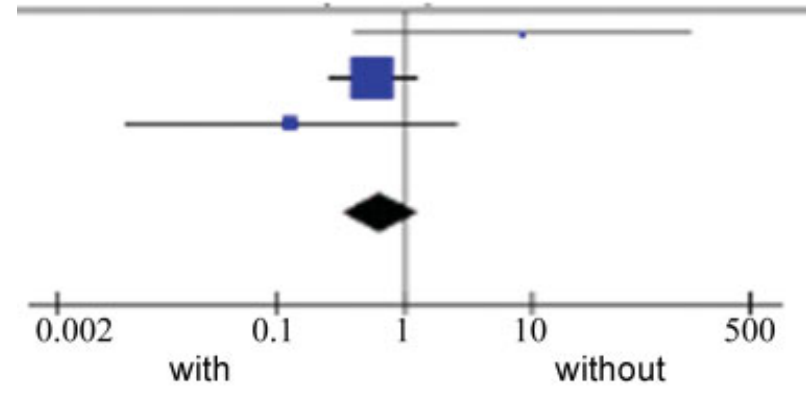

Fig. 4 Reoperation rate in surgery for POP with and without vaginal mesh.

the group without mesh reported bulge resolution, without statistical difference: $\mathrm{OR}=0.65(\mathrm{CI}=0.83-1.29)$.

\section{Dyspareunia}

For dyspareunia rate evaluation, 6 articles were included (397 women), without significant heterogeneity. In the mesh group, dyspareunia was found in 15/193 patients, while it was found in 16/204 women in the group without mesh, showing no statistical difference: $\mathrm{OR}=0.94(\mathrm{CI}=0.45$ 1.96).

\section{Quality of life validated questionnaires (- Fig. 5)}

For sexual function analysis, through the PISQ-12 questionnaire, 3 articles were enrolled, with a total of 612 women. The mean difference between groups was -0.38 (from -3.12 to 2.37), without statistical significance.

The subjective assessment through the P-QOL questionnaire included 2 articles, with 164 women. There was no significant heterogeneity among studies. The results showed no statistical difference in quality of life after surgery with or without mesh, with a mean difference of -0.94 (from -3.31 to 1.42).

The PFIQ-7 quality of life questionnaire evaluation included 2 articles, totaling 137 women. There was no significant difference between groups, with a mean difference of -0.77 (from -14.25 to 12.74) after aleatory effect analysis.

Finally, the PFDI-20 questionnaire was analyzed including 2 articles (139 women), also without statistical difference between groups, with a mean difference of 0.20 (from -19.95 to 19.66) after aleatory effect analysis.

\section{Discussion}

This meta-analysis showed that the use of meshes for the treatment of anterior vaginal wall prolapse is superior to native tissue surgical repair, when objective cure through POP-Q assessment is considered. ${ }^{14-25}$ All of the articles included in this meta-analysis considered as an objective cure criterion a post-surgical POP-Q stage inferior to 2 in the pelvic examination. This definition of cure, that is, when the prolapse's maximum extent stays at least $1 \mathrm{~cm}$ above the hymenal ring, is based on the recommendations of the US National Institute of Health (NIH) workshop. ${ }^{26}$

However, this POP-Q based cure assessment has been criticized by many authors - many discrete or moderate prolapses are not classified using this criterion as cure or 


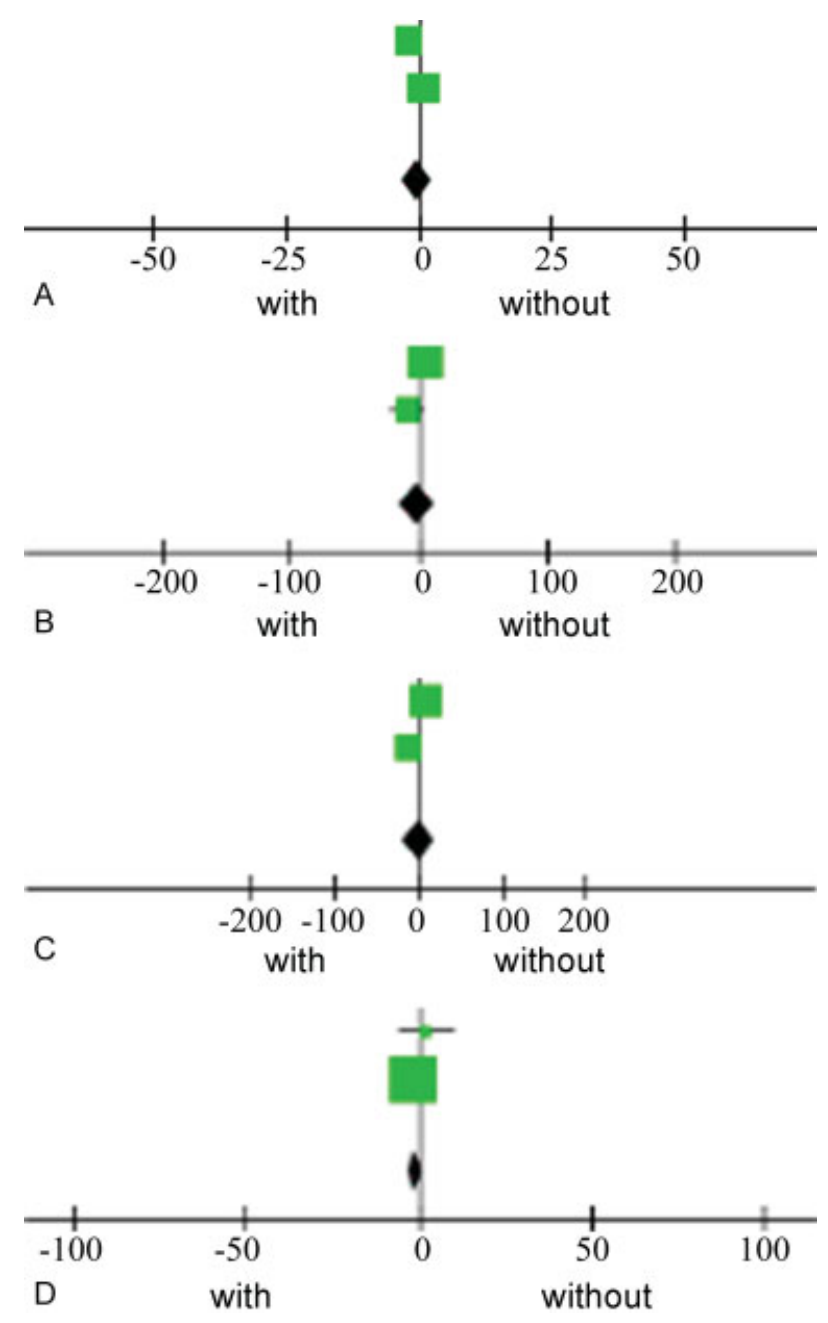

Fig. 5 Quality of life after POP surgery with or without mesh.

absence of prolapse, although they have no impact on women's quality of life and, therefore, demand no intervention. $^{27,28}$

For the prolapse patient, the main goal is symptom relief and quality of life improvement; accordingly, quality of life assessment in these cases seems more trustworthy than the POP-Q classification alone.

There are several different ways to assess quality of life, with the use of subjective criteria or validated questionnaires. This meta-analysis showed no significant results when evaluating the "vaginal bulge" symptom resolution, with no statistical difference between the groups with or without the use of mesh; but an aleatory effect analysis had to be made due to the great heterogeneity among studies.

Aleatory effect meta-analysis adds variance to the general effect proportionally to the variability of the results in the studies; that makes the confidence intervals of the estimated summary measure be bigger than those of the fixed effect meta-analysis.

When we evaluated quality of life using 4 different validated questionnaires (PISQ-12, P-QOL, PFIQ-7 and PFDI-20), we observed no significant difference in quality of life rating between women submitted to prolapse surgery with or without mesh use. A previous Cochrane Metaanalysis also concluded that although anterior vaginal mesh placement shows better anatomical results, it does not promote better functional outcomes. ${ }^{5}$

Furthermore, our study showed that women submitted to mesh surgery have lower prolapse recurrence rates $(80 \%$ less), without heterogeneity among analyzed articles, which increases this result's credibility. The risk of a woman having to go through surgery for pelvic prolapse during her entire life is $\sim 6-19 \%$, with $30 \%$ chance of a new intervention for recurrence of the prolapse. ${ }^{29,30}$

Moreover, reoperation rates after reconstructive prolapse surgery are very high (43-58\%), ${ }^{31,32}$ which led to the use of synthetic meshes in the last decades, in an attempt to lower those flawed outcomes. This meta-analysis shows that the use of vaginal meshes is effective in diminishing recurrence rates; nevertheless, with increased surgery duration and blood loss, which may increase procedure-related morbidity.

The use of vaginal meshes is not free of risk. The main complications are: vaginal mesh erosion; infection; granulomas; dyspareunia; vesicovaginal fistula; and chronic pelvic pain. In 2008, the American Food and Drug Administration (FDA) released its first notification about the complications associated to the use of synthetic meshes, after receiving more than one thousand complication reports. In 2011, the FDA released two more statements about indications and security concerning mesh use. ${ }^{33}$

This meta-analysis revealed a 7,4\% medium rate of mesh erosion (3.2-19\%). Mesh erosion or exposure rate varies with follow-up time, being observed from 6 weeks up to 7 years after the surgical procedure. Studies included in this metaanalysis had at least 1 year of follow-up; however, this may be considered a short time for this particular evaluation, explaining the low rate of extrusion observed.

Therefore, albeit the benefit of less prolapse recurrence, mesh surgery should be evaluated carefully, given the fact of morbidity elevation (longer surgeries and greater blood loss) and related extrusion rates. Furthermore, there was no difference in reoperation rates comparing mesh versus no mesh surgery - the most probable explanation for this fact is that maybe recurrence did not affect substantially those women's quality of life to the point that a new surgical approach was needed.

There was no significant difference in de novo dyspareunia rates between mesh and no-mesh groups. Dyspareunia is, as stated above, one of the main complications associated with the use of vaginal meshes, and is a very important aspect to be considered in women with prolapse, especially those who wish to maintain a sexual healthy sexual life after surgery, being directly related to patient satisfaction and quality of life. This meta-analysis also showed that there was no statistical difference in quality of sexual life in women with and without mesh, evaluated through the PISQ-12 questionnaire. The fact that women submitted to mesh surgery did not show greater dyspareunia rates or significant mesh erosion in our report may have contributed to this sexual life equality between groups. 


\section{Conclusions}

Female genital prolapses are a great cause of quality of life prejudice, with sexual, psychological and functional (defecation and micturition) impairment. ${ }^{4,5}$ Costs related to female POP surgery are high and growing worldwide. A 46\% rise in corrective pelvic surgeries is expected in the next decades, due mainly to population aging. ${ }^{34,35}$

The choice of an effective and safe treatment for genital prolapse is really important, and another fact to be taken into consideration, especially in the anterior vaginal wall defects, is that they are frequently associated with defects of the vaginal apex. Women with anterior vaginal stage 3 (POP-Q) prolapses have up to $98 \%$ chance of having a concomitant uterus/vault prolapse of at least the first stage $\mathrm{e}^{36}$ - this association and its correction were not taken into consideration in many studies assessed in this meta-analysis.

Despite many strong points, such as inclusion of only randomized controlled trials of the past 15 years with minimum follow-up of 1 year, and with paper quality addressed by Jadad criteria, this meta-analysis has some limitations, mainly because of study heterogeneity, great difference in quality of life evaluation among studies, short follow-up for the appearance of certain late complications, such as mesh extrusion and recurrence, and the lack of a clear apex evaluation/treatment in the trials.

Future studies with longer follow-up and inclusion of an apex thorough evaluation and concomitant treatment when operating the anterior vaginal wall are necessary to better enlighten the definitive role of vaginal meshes in this scenario.

\section{References}

1 Maher C. Anterior vaginal compartment surgery. Int Urogynecol J 2013;24(11):1791-1802

2 Brincat CA, Larson KA, Fenner DE. Anterior vaginal wall prolapse: assessment and treatment. Clin Obstet Gynecol 2010;53(1): 51-58

3 Lensen EJ, Withagen MI, Kluivers KB, Milani AL, Vierhout ME. Surgical treatment of pelvic organ prolapse: a historical review with emphasis on the anterior compartment. Int Urogynecol J 2013;24(10):1593-1602

4 Giarenis I, Robinson D. Prevention and management of pelvic organ prolapse. F1000Prime Rep 2014;6:77

5 Maher C, Feiner B, Baessler K, Schmid C. Surgical management of pelvic organ prolapse in women. Cochrane Database Syst Rev 2013;4(4):CD004014

6 Liberati A, Altman DG, Tetzlaff J, et al. The PRISMA statement for reporting systematic reviews and meta-analyses of studies that evaluate health care interventions: explanation and elaboration. J Clin Epidemiol 2009;62(10):e1-e34

7 Bump RC, Mattiasson A, Bø K, et al. The standardization of terminology of female pelvic organ prolapse and pelvic floor dysfunction. Am J Obstet Gynecol 1996;175(1):10-17

8 Jadad AR, Moore RA, Carroll D, et al. Assessing the quality of reports of randomized clinical trials: is blinding necessary? Control Clin Trials 1996;17(1):1-12

9 Rogers RG, Coates KW, Kammerer-Doak D, Khalsa S, Qualls C. A short form of the Pelvic Organ Prolapse/Urinary Incontinence
Sexual Questionnaire (PISQ-12). Int Urogynecol J Pelvic Floor Dysfunct 2003;14(3):164-168, discussion 168

10 Barber MD, Walters MD, Bump RC. Short forms of two conditionspecific quality-of-life questionnaires for women with pelvic floor disorders (PFDI-20 and PFIQ-7). Am J Obstet Gynecol 2005; 193(1):103-113

11 Digesu GA, Khullar V, Cardozo L, Robinson D, Salvatore S. P-QOL: a validated questionnaire to assess the symptoms and quality of life of women with urogenital prolapse. Int Urogynecol J Pelvic Floor Dysfunct 2005;16(3):176-181, discussion 181

12 Cochrane's Informatics \& Knowledge Management Department (IKMD). Review Manager (RevMan) [Computer program]. Version 5.3. Copenhagen: The Nordic Cochrane Centre; 2014

13 Hulley SB, Cummings ST, Browner WS, Grady DG, Newman TB. [Designing clinical research]. 4th ed. Porto Alegre: Artmed; 2015. Portuguese.

14 Altman D, Väyrynen T, Engh ME, Axelsen S, Falconer C; Nordic Transvaginal Mesh Group. Anterior colporrhaphy versus transvaginal mesh for pelvic-organ prolapse. N Engl J Med 2011; 364(19):1826-1836

15 de Tayrac R, Cornille A, Eglin G, et al. Comparison between transobturator trans-vaginal mesh and traditional anterior colporrhaphy in the treatment of anterior vaginal wall prolapse: results of a French RCT. Int Urogynecol J 2013;24(10):1651-1661

16 Delroy CA, Castro RdeA, Dias MM, et al. The use of transvaginal synthetic mesh for anterior vaginal wall prolapse repair: a randomized controlled trial. Int Urogynecol J 2013;24(11): 1899-1907

17 El-Nazer MA, Gomaa IA, Ismail Madkour WA, Swidan KH, ElEtriby MA. Anterior colporrhaphy versus repair with mesh for anterior vaginal wall prolapse: a comparative clinical study. Arch Gynecol Obstet 2012;286(4):965-972

18 Gutman RE, Nosti PA, Sokol AI, et al. Three-year outcomes of vaginal mesh for prolapse: a randomized controlled trial. Obstet Gynecol 2013;122(4):770-777

19 Hiltunen R, Nieminen K, Takala T, et al. Low-weight polypropylene mesh for anterior vaginal wall prolapse: a randomized controlled trial. Obstet Gynecol 2007;110(2 Pt 2):455-462

20 Lamblin G, Van-Nieuwenhuyse A, Chabert P, Lebail-Carval K, Moret S, Mellier G. A randomized controlled trial comparing anatomical and functional outcome between vaginal colposuspension and transvaginal mesh. Int Urogynecol J 2014;25(7): 961-970

21 Nguyen JN, Burchette RJ. Outcome after anterior vaginal prolapse repair: a randomized controlled trial. Obstet Gynecol 2008; 111(4):891-898

22 Nieminen $\mathrm{K}$, Hiltunen R, Takala $\mathrm{T}$, et al. Outcomes after anterior vaginal wall repair with mesh: a randomized, controlled trial with a 3. year follow-up. Am J Obstet Gynecol 2010;203(3):235.e1-235.e8 23 Sivaslioglu AA, Unlubilgin E, Dolen I. A randomized comparison of polypropylene mesh surgery with site-specific surgery in the treatment of cystocoele. Int Urogynecol J Pelvic Floor Dysfunct 2008;19(4):467-471

24 Tamanini JTN, Tamanini MMM, Castro RCO, et al. Treatment of anterior vaginal wall prolapse with and without polypropylene mesh: a prospective, randomized and controlled trial - Part I. Int Braz J Urol 2013;39(4):519-530

25 Vollebregt A, Fischer K, Gietelink D, van der Vaart CH. Primary surgical repair of anterior vaginal prolapse: a randomised trial comparing anatomical and functional outcome between anterior colporrhaphy and trocar-guided transobturator anterior mesh. BJOG 2011;118(12):1518-1527

26 Weber AM, Abrams P, Brubaker L, et al. The standardization of terminology for researchers in female pelvic floor disorders. Int Urogynecol J Pelvic Floor Dysfunct 2001;12(3):178-186

27 Barber MD. Symptoms and outcome measures of pelvic organ prolapse. Clin Obstet Gynecol 2005;48(3):648-661 
28 Chmielewski L, Walters MD, Weber AM, Barber MD. Reanalysis of a randomized trial of 3 techniques of anterior colporrhaphy using clinically relevant definitions of success. Am J Obstet Gynecol 2011;205(1):69.e1-69.e8

29 Olsen AL, Smith VJ, Bergstrom JO, Colling JC, Clark AL. Epidemiology of surgically managed pelvic organ prolapse and urinary incontinence. Obstet Gynecol 1997;89(4):501-506

30 Fialkow MF, Newton KM, Lentz GM, Weiss NS. Lifetime risk of surgical management for pelvic organ prolapse or urinary incontinence. Int Urogynecol J Pelvic Floor Dysfunct 2008;19(3):437-440

31 Clark AL, Gregory T, Smith VJ, Edwards R. Epidemiologic evaluation of reoperation for surgically treated pelvic organ prolapse and urinary incontinence. Am J Obstet Gynecol 2003;189(5):1261-1267

32 Whiteside JL, Weber AM, Meyn LA, Walters MD. Risk factors for prolapse recurrence after vaginal repair. Am J Obstet Gynecol 2004;191(5):1533-1538
33 U.S. Food and Drug Administration. (FDA). Center for Devices and Radiological Health (CDRH) [Internet]. Urogynecologic surgical mesh: update on the safety of transvaginal placement for pelvic organ prolapse. Jul 2011 [cited 2015 May 10]. Available from: http://www.fda.gov/downloads/MedicalDevices/Safety/AlertsandNotices/UCM262760.pdf

34 Cheon C, Maher C. Economics of pelvic organ prolapse surgery. Int Urogynecol J 2013;24(11):1873-1876

35 Jacklin P, Duckett J. A decision-analytic Markov model to compare the cost-utility of anterior repair augmented with synthetic mesh compared with non-mesh repair in women with surgically treated prolapse. BJOG 2013;120(2): 217-223

36 Elliott CS, Yeh J, Comiter CV, Chen B, Sokol ER. The predictive value of a cystocele for concomitant vaginal apical prolapse. J Urol 2013; 189(1):200-203 